\title{
GOOD CORPORATE GOVERNANCE PENGARUHNYA PADA KINERJA KEUANGAN PERBANKAN SYARIAH DI INDONESIA
}

\author{
Lely Ana Ferawati Ekaningsih ${ }^{1 *}$, Futhri Izza Afkarina ${ }^{1}$ \\ 'Institut Agama Islam Darussalam, Blokagung Banyuwangi, Indonesia \\ "Korespondensi: lafwens@gmail.com
}

\begin{abstract}
The implementation of GCG is very important in a bank to improve banking performance, especially the financial performance of Islamic banking. Financial performance is one of the tools used to measure whether the banking performance is going well or not. This study aims to analyze the effect of Good Corporate Governance (GCG)/X on financial performance (ROA)/Y. This type of research is quantitative, using secondary data. The population is all Islamic banks registered with the OJK. While the sampling technique used purposive sampling method, namely 8 Islamic banks which were then multiplied by 3 years until the final sample was 24 samples. The data analysis technique used simple linear regression analysis. The results of this study indicate that GCG has a significant effect on financial performance. This is evidenced by the composite average value of Islamic banking which has the predicate "Good". While the average value of the ROA has increased. This research is in accordance with the statement that the implementation of GCG is very useful for improving financial performance, the better the GCG, the better the performance.
\end{abstract}

Keywords: Good Corporate Governance, ROA, Islamic Financial Management

\begin{abstract}
ABSTRAK
Penerapan GCG sangat penting dalam sebuah perbankan untuk meningkatkan kinerja perbankan khususnya kinerja keuangan perbankan syariah. Kinerja keuangan merupakan salah satu alat yang digunakan untuk mengukur apakah kinerja perbankan itu berjalan dengan baik atau tidak. Penelitian ini bertujuan untuk menganalisis Good Corporate Governance (GCG)/X berpengaruh pada kinerja keuangan $(\mathrm{ROA}) /$ Y. Jenis penelitian ini kuantitatif, menggunakan data sekunder. Populasinya adalah seluruh bank syariah yang terdaftar di OJK. Sedangkan teknik pengumpulan sampel menggunakan metode purposive sampling, yakni 8 bank syariah yang kemudian dikalikan 3 tahun hingga sampel akhir sebanyak 24 sampel. Teknik analisis datamenggunakan analisis regresi linier sederhana. Hasil penelitian ini menunjukkan bahwa GCG berpengaruh signifikan terhadap kinerja keuangan. Hal ini dibuktikan oleh nilai rata-rata komposit perbankan syariah memiliki predikat "Baik". Sedangkan nilai rata-rata ROAnya mengalami peningkatan. Penelitian ini sesuai dengan pernyataan bahwa penerapan GCG sangat bermanfaat untuk meningkatkan kinerja keuangan, semakin baik GCG yang dimiliki maka semakin baik pula kinerjanya.
\end{abstract}

Kata kunci: Tata Kelola, ROA, Manajemen Keuangan Syariah. 


\section{PENDAHULUAN}

Hakikatnya setiap manusia selalu berusaha untuk memenuhi segala kebutuhan dalam hidupnya. Dalam setiap usahanya, pasti akan membutuhkan bantuan orang lain. Hal tersebut dapat menimbulkan interaksi antar perorangan untuk meningkatkan taraf hidup masing-masing. Terpenuhinya sandang, pangan maupun papan merupakan tolok ukur meningkatnya taraf hidup. Dalam pemenuhannya perlu adanya manajemen dalam mengatur keuangan seperti halnya menabung di bank, agar kebutuhan di masa mendatang tetap terpenuhi. Di era modern ini, bank menjadi salah satu aspek penting dalam perekonomian, yang mana bank berperan sebagai fasilitator dalam kegiatan perbankan. Bank menurut operasionalnya dibedakan menjadi dua yakni bank konvensional dan bank syariah. Bank syariah merupakan lembaga keuangan yang beroperasi berdasarkan pada syariat Islam (Ekaningsih dkk, 2016:15).

Perkembangan perbankan syariah di Indonesia saat ini cukup pesat. Hal ini didukung dengan mayoritas warga Indonesia yang beragama Islam dan banyaknya minat nasabah terhadap perbankan yang berasaskan hukum Islam. Lahirnya Undang-undang No. 21 Tahun 2008 tentang Perbankan Syariah merupakan landasan hukum yang kuat yang secara khusus mengatur perbankan syariah serta memberikan keyakinan kepada masyarakat dalam menggunakan produk dan jasa bank syariah. Hal ini kemudian menjadikan perkembangan perbankan syariah semakin pesat di Indonesia (Nugroho, 2015:3). Hingga saat ini,jumlah bank syariah yang berkembang menurut data statistik Perbankan Syariah yang dikeluarkan oleh Otoritas Jasa keuangan (OJK) pada April 2018, bank syariah di Indonesia terdapat 13 Bank Umum Syariah (BUS), 21 Unit Usaha Syariah (UUS) dan 168 BPRS (OJK, 2018).Otoritas Jasa Keuangan (OJK) merupakan lembaga negara yang dibentuk berdasarkan Undang-undang Nomor 21 Tahun 2011 yang berfungsi menyelenggarakan sistem pengaturan dan pengawasan yang terintegrasi terhadap keseluruhan kegiatan di dalam sektor jasa keuangan baik di sektor perbankan, pasar modal, dan sektor jasa keuangan non-bank seperti Asuransi, Dana Pensiun, Lembaga Pembiayaan, dan Lembaga Jasa Keuangan lainnya.

Indonesia di tahun 2013 sempat mengalami krisis yang salah satunya berdampak pada perbankan syariah. Krisis yang dialami Indonesia tidak jauh berbeda dengan krisis pada tahun 2008. Hal ini ditandai dengan menurunnya nilai kurs rupiah terhadap dolar (Chatib, 2013). Kebangkrutan yang dialami oleh Perbankan Indonesia semata-mata bukan hanya akibat dari krisis ekonomi, tetapi juga diakibatkan karena belum diterapkannya Good Corporate Governance (GCG) dan etika yang melandasinya (Abdullah, 2010:65).

Penerapan tata kelola perusahaan yang baik (GCG) telah menjadi salah satu indikator keberhasilan perusahaan (Ahmad et al., 2021). Penerapan GCG sangat penting dalam sebuah perbankan untuk meningkatkan kinerja perbankan. Kinerja keuangan merupakan salah satu alat yang digunakan untuk mengukur apakah kinerja perbankan itu berjalan dengan baik atau tidak. Bank syariah yang belum sepenuhnya menerapkan GCG dapat memicu timbulnya kecurangan, seperti korupsi, kolusi, nepotisme (KKN) dan hal lainnya yang dapat menyebabkan kebangkrutan. Fenomena ini, dapat menurunkan kepercayaan investor terhadap bank tersebut. Oleh sebab itu, salah satu upaya untuk mengembalikan kepercayaan masyarakat terhadap dunia perbankan dan meningkatkan kinerja perbankan yakni dengan menerapkan GCG (Abdullah, 2010:65).

Terlaksananya Good Corporate Governance pada perbankan syariah di Indonesia merupakan awal dari perubahan budaya kerja perbankan. Untuk meningkatkan kinerja perbankan perlu adanya persiapan yang baik. Perencanaan program kerja yang baik terbentuk dari strategi perbankan yang baik pula yang pada akhirnya dapat meningkatkan keuntungan atau laba perbankan. Pencapaian 
target keuntungan sangat penting karena tercapainya sebuah target atau bahkan lebih merupakan sebuah prestasi yang baik. Ketika keuntungan yang didapat oleh perbankan itu baik, maka ini merupakan awal dari sebuah perbankan itu dikatakan sukses. Keuntungan yang diperoleh perbankan dapat dilihat dari bagaimana kinerja perbankan tersebut (Kasmir, 2015:2).

Pengukuran kinerja keuangan merupakan salah satu faktor yang sangat penting bagi perusahaan, karena pengukuran tersebut digunakan sebagai dasar untuk menyusun sistem imbalan dalam perusahaan yang dapat mempengaruhi perilaku pengambilan keputusan dalam perusahaan. Pengukuran kinerja keuangan umumnya dilakukan dengan menganalisis laporan keuangan seperti rasio profitabilitas (Ekaningsih, 2011). Rasio profitabillitas merupakan rasio untuk mengukur kemampuan perbankan dalam mencari keuntungan. Hal ini bisa tercapai sebab adanya kerja sama dan tata tata kelola perusahaan yang baik dari seluruh komponen perusahaan. Sehingga penerapan Good Corporate Governance pada perbankan syariah tidak hanya memberikan keuntungan bagi perbankan akan tetapi juga bagi masyarakat. Berdasarkan uraian diatas, penelitian ini mengalisis Good Corporate Governance (GCG) (X) berpengaruh pada kinerja keuangan (Y) perbankan syariah di Indonesia periode tahun 2016-2018. bBanyak penelitian yang menggunakan struktur tata kelola sebagai proxy dari variabel GCG, namun dalam penelitian ini menggunakan penilaian self assessment sebagai proxy variabel GCG.

Manajemen keuangan syariah dapat diartikan sebagai kegiatan perencanaan, pengorganisasian, staffing, pelaksanaan, dan pengendalian fungsi-fungsi keuangan yang dituntun oleh prinsip-prinsip syariah (Muhammad, 2016:2). Menurut Fahmi (2012:4) tujuan manajemen keuangan yakni memaksimumkan nilai perusahaan, menjaga stabilitas finansial dalam keadaan yang selalu terkendali serta memperkecil risiko perusahaan di masa sekarang dan masa mendatang.

Muhammad (2016:8) mengatakan bahwa fungsi manajemen keuangan syariah berkaitan dengan keputusan keuangan yang meliputi empat fungsi utama, yaitu: keputusan investasi, keputusan pendanaan, keputusan bagi hasil, keputusan zakat perusahaan. Sedangkan laporan keuangan untuk entitas syariah terdiri dari: neraca, laporan laba rugi, laporan arus kas, laporan perubahan ekuitas, laporan sumber dan penggunaan dana zakat, infak dan shadaqah, laporan sumber dan penggunaan dana qardhul hasan.

Kinerja keuangan adalah gambaran akan keberhasilan perusahaan berupa hasil yang telah dicapai dengan berbagai kegiatan yang telah dilakukan. Kinerja keuangan merupakan suatu analisis untuk menilai sejauh mana suatu perusahaan melaksanakan aktivitasnya sesuai dengan aturan pelaksanaan keuangan. Kinerja keuangan dapat diukur dengan menggunakan rasio keuangan (Fahmi, 2012:2). Menurut Suwiknyo (2010:147) menyatakan bahwa analisis rasio keuangan bank syariah masih menggunakan aturan yang berlaku di bank konvensional hanya beda istilah saja, seperti dalam bank konvensional menggunakan kata "bunga", sedangkan dalam bank syariah menggunakan kata "bagi hasil”.

Kasmir (2015:104) mengatakan rasio keuangan adalah aktivitas membandingkan angka-angka yang ada dalam laporan keuangan dengan cara membagi satu angka ke angka lainnya. Mamduh dan Halim (2016:74) membagi macam rasio keuangan menjadi lima, yaitu: rasio likuiditas, rasio aktivitas, rasio solvabilitas, rasio profitabilitas, rasio pasar. Penelitian ini menggunakan rasio profitabilitas sebagai alat ukur kinerja keuangan dari sebuah perusahaan untuk mengetahui penghasilan dan perkembangan laba perbankan syariah di Indonesia selama periode tahun 2016-2018.

Secara umum tata kelola perusahaan adalah rangkaian kebijakan, proses, aturan, dan institusi yang mempengaruhi pengelolaan, serta pengontrolan suatu perusahaan. Tata kelola perusahaan juga mencakup hubungan antar para pemilik 
kepentingan (stakeholder) yang terlibat serta tujuan pengelolaan perusahaan. Pihakpihak utama dalam tata kelola perusahaan adalah dewan direksi, pemegang saham dan manajemen (Wibowo, 2010:129). Menurut Abdullah (2010:71) prinsip GCG meliputi: transparansi (transparency), akuntabilitas (accountability), pertanggungjawaban (responsibility), independensi (indenpendency), dan kewajaran (fairness). Menurut Prabowo (2018:3) salah satu manfaat GCG ialah meningkatkan kinerja perusahaan melalui prosedur pengambilan keputusan yang lebih baik, kegiatan operasi yang lebih efisien dan pemberian layanan yang lebih baik, sebagai akses terhadap pembiayaan dengan biaya rendah bagi teknologi-teknologi baru, pasar, keahlian manajemen dan sumber-sumber pembiayaan lainnya yang akan meningkatkan nilai perusahaan.

Penerapan GCG merupakan bukti pertanggungjawaban bank syariah atas masyarakat bahwa suatu bank syariah dikelola dengan baik, hati-hati, dan profesional dengan tetap berusaha meningkatkan nilai pemegang saham tanpa mengabaikan kepentingan stakeholders lainnya. Perbankan syariah sebagai lembaga keuangan yang terkenal sangat membutuhkan adanya kepercayaan dari masyarakat. Maka dari itu, diperlukan adanya kesinambungan dan upaya bank syariah untuk melaksanakan prinsip-prinsip GCG.

Bank syariah adalah bank yang beroperasi dengan prinsip tidak mengandalkan pada bunga. Bank syariah juga dapat didefinisikan sebagai lembaga keuangan/perbankan yang produk dan operasionalnya dikembangkan berdasarkan Al-Quran dan hadist Nabi SAW (Umam, 2013:105). Salah satu penelitian terdahulu yang digunakan dalam penelitian ini adalah penelitian yang dilakukan oleh Arry Eksandy tahun 2018. Hasil penelitiannya menunjukkan bahwa variabel dewan direksi berpengaruh signifikan terhadap kinerja keuangan. Sedangkan variabel dewan komisaris, dewan pengawas syariah dan komite audit tidak berpengaruh signifikan terhadap kinerja keuangan. Selain itu juga bank perlu menjaga kinerjanya agar dapat beroperasi secara optimal. Terlebih lagi bank syariah harus bersaing dengan bank konvensional yang dominan dan telah berkembang pesat di Indonesia (Ekaningsih dan Rozi, 2012).

\section{METODE PENELITIAN}

\section{Jenis Penelitian}

Penelitian ini termasuk penelitian deskriptif dengan pendekatan eksplanatori/penelitian penjelasan (Explanatory Reseach). Explanatory Reseach merupakan bentuk metode penelitian yang bertujuan untuk menjelaskan pengaruh antara satu variabel dengan variabel lain serta menjelaskan tentang kedudukan setiap variabel yang diteliti (Sugiyono, 2014:4). Exploratory research dalam penelitian ini dilakukan dengan cara mengumpulkan data yang telah dipublikasikan oleh masing-masing bank syariah. Kemudian data yang sudah diperoleh digunakan untuk menghitung variabel GCG (X) dan variabel kinerja keuangan (Y) untuk dianalisis pengaruhnya serta diambil kesimpulannya untuk menjawab hipotesis.

\section{Lokasi}

Penelitian ini dilakukan pada 8 Bank Syariah di Indonesia yang tercatat di Otoritas Jasa Keuangan (OJK) antara lain: Bank Mandiri Syariah, Bank Muamalat Indonesia, Bank Rakyat Indonesia Syariah, Bank Negara Indonesia Syariah, Bank Central Asia Syariah, Bank Mega Syariah, Bank Bukopin Syariah, Bank Tabungan Pensiunan Nasional Syariah.

\section{Sumber Data}

Sumber data yang digunakan dalam penelitian ini adalah hanya berasal dari data sekunder. Data sekunder adalah data yang diambil peneliti dari semua sumber 
yang sudah ada. Data sekunder biasanya berasal dari penelitian yang sudah dilakukan oleh orang atau lembaga lain (Subagiyo, 2017:74). Dalam penelitian ini menggunakan entitas laporan keuangan syariah berupa neraca, laporan laba rugi dan laporan GCG masing-masing bank periode 2016-2018 dalam bentuk Annual Report.

\section{Teknik Pengumpulan Data}

Teknik pengumpulan data yang digunakan dalam penelitian ini menggunakan Metode dokumentasi. Metode dokumentasi dilakukan dengan mencari data mengenai hal-hal atau veriabel yang berupa buku, catatan, transkip, surat kabar, prasasti, majalah, notulen rapat, lengger, agenda dan sebagainya (Arikunto, 2014:274). Dalam penelitian ini, pengumpulan data diawali dengan mencari data melalui transkip laporan tahunan masing-masing bank dalam bentuk Annual Report yang berhubungan dengan Good Corporate Governance (GCG), dan rasio profitabilitas (ROA) baik dari segi pengertian maupun cara perhitungannya. Pada tahap ini dilakukan pemilihan data-data sebagai sumber referensi penelitian mengenai jenis data yang dibutuhkan, ketersediaan data, dan gambaran pengolahan data dari sumber/referensi yang telah didapatkan. Tahap selanjutnya yaitu mengumpulkan keseluruhan data untuk diolah dan dianalisis melalui teknik/metode analisis data guna menjawab penelitian.

\section{Alat Analisis Data}

Sugiyono (2016:147) mengatakan bahwa analisis data merupakan kegiatan setelah data dari seluruh responden atau sumber data lain terkumpul. Dalam penelitian ini alat analisis menggunakan analisis regresi linier sederhana. Analisis regresi sederhana digunakan untuk menilai bagaimana keadaan (naik turunya) variabel terikat, bila dua atau lebih variabel bebas sebagai faktor prediktor dimanipulasi (dinaikturunkan). Ketentuan dalam analisis regresi linier sederhana adalah data yang digunakan harus sudah diuji validitas, reliabilitas dan normalitasnya terlebih dahulu. Apabila data sudah valid, reliabel dan normal maka data bisa dianalisis. Namun dalam penelitian ini tidak melakukan uji validitas dan uji reliabilitas tetapi hanya menggunakan uji normalitas dikarenakan data yang digunakan berupa data rasio. Menurut Usman dan Akbar (2008:19) data rasio merupakan jenis data yang memiliki tingkatan tertinggi, data yang memiliki sifatsifat interval dan selain itu data tersebut mempunyai nilai nol mutlak.

\section{Uji Normalitas}

Uji normalitas dilakukan untuk menguji apakah data yang dihitung dalam model regresi berdistribusi normal atau tidak. Data yang berdistribusi normal dianalisis dengan regresi sederhana. Uji normalitas dapat dilakukan dengan menggunakan aplikasi SPSS. Dalam penelitian ini, uji normalitas dapat dilakukan dengan pengujian Kolmogorov-Smirnov test dengan menetapkan derajat keyakinan $(\alpha)$ sebesar 5\%. Jika signifikansi $\geq 0,05$ berarti data distribusinya normal. Jika signifikansi $\leq$ 0,05 berarti data tidak berdistribusi normal(Ghozali, 2006:32).

\section{Uji Regresi Linier Sederhana}

Menurut Muhid (2012:118) formulasi persamaan regresi linier sederhana sebagai berikut:

Keterangan:

$$
\mathrm{Y}=\mathrm{a}+\mathrm{bX}
$$

$\mathrm{Y}=$ Subjek dalam variabel bebas (independent variabel) yang diprediksikan

$\mathrm{a}=$ Harga $\mathrm{Y}$ bila $\mathrm{X}=0$ (harga konstan)

$\mathrm{b}=$ Angka arah atau nilai koefisien regresi, yang menunjukkan angka peningkatan ataupun penurunan variabel tergantung (dependent 
variabel). Bila b positif (+) maka naik, dan bila negatif (-) maka terjadi penurunan.

$\mathrm{X}=$ Subjek pada variabel bebas (independent variabel) yang mempunyai nilai tertentu.

Dengan taraf signifikansi 0,05. Jika pada tabel ANOVA nilai $\mathrm{p} \geq 0,05$ maka Ho diterima artinya tidak signifikan. Dan jika nilai $\mathrm{p} \leq 0,05$ maka Ho ditolak artinya signifikan. Dengan rumus regresi linier sederhana di atas maka akan diketahui seberapa besar pengaruh dari variabel independen $(\mathrm{X})$ terhadap variabel dependen (Y).

\section{HASIL DAN PEMBAHASAN}

\section{Hasil Analisis Data}

Untuk menjawab rumusan masalah, maka dilakukan langkah-langkah menjawab analisis regresi linier sederhana. Namun sebelum melakukan uji analisis regresi linier sederhana, maka terlebih dahulu dilakukan uji normalitas.

\section{Uji normalitas}

Bedasarkan hasil uji normalitas dengan menggunakan One-Sample Kolmogorov-Smirnov Test menunjukkan bahwa nilai Asymp. Sig. pada tabel jika dibandingkan dengan nilai probabilitas lebih besar daripada 0,05 ( $\mathrm{p} \geq 0,05)$. Hal ini menunjukkan bahwa variabel pada penelitian ini berdistribusi normal.

\section{Analisis regresi linier sederhana}

Analisis regresi linier digunakan untuk melihat ada tidaknya pengaruh variabel independen terhadap variabel dependen sebuah penelitian. Adapun penyelesaian regresi linier sederhana penelitian ini sebagai berikut. Persamaan regresi linier sederhana dinyatakan dalam bentuk: $\mathrm{Y}=\mathrm{a}+\mathrm{bX}$. Berikut hasil uji persamaan regresi linier sederhana:

Tabel 1 Hasil Uji Persamaan Regresi Linier Sederhana Coefficients $^{a}$

\begin{tabular}{|c|c|c|c|c|c|}
\hline \multirow[b]{2}{*}{ Model } & $\begin{array}{r}\text { Unstand } \\
\text { Coeffi }\end{array}$ & $\begin{array}{l}\text { rdized } \\
\text { ients }\end{array}$ & $\begin{array}{c}\text { Standardize } \\
\mathrm{d} \\
\text { Coefficients } \\
\end{array}$ & \multirow[b]{2}{*}{$\mathrm{T}$} & \multirow[b]{2}{*}{ Sig. } \\
\hline & B & $\begin{array}{l}\text { Std. } \\
\text { Error }\end{array}$ & Beta & & \\
\hline $\begin{array}{ll}1 & \text { (Constant) } \\
\mathrm{X}\end{array}$ & $\begin{array}{r}-2,951 \\
2,547\end{array}$ & $\begin{array}{r}1,389 \\
, 785\end{array}$ & ,569 & $\begin{array}{r}-2,125 \\
3,946\end{array}$ & $\begin{array}{l}, 045 \\
, 004\end{array}$ \\
\hline
\end{tabular}

a. Dependent Variable: Y

Berdasarkan tabel 1 persamaan regresi linear sederhana dapat disusun sebagai berikut: $Y=-2,951+2,547 X$. Persamaan regresi linear sederhana dapat diinterprestasikan sebagai berikut:

a. Unstandardized Coefficients (Constant) sebesar -2,951 adalah nilai ROA tanpa kehadiran variabel independen yaitu Good Corporate Governance (X).

b. Unstandardized Coefficients GCG (X) sebesar 2,547 menyatakan bahwa jika GCG (X) baik dan tepat maka kinerja keuangan akan naik sebesar 2,547.

Standart Error (Constant) sebesar 1,389 yang menunjukkan penyimpangan dari konstanta yang ada dalam model persamaan regresi. Stdandart Error GCG (X) sebesar 0,785 yang menunjukkan penyimpangan koefisien regresi variabel GCG (X). Semakin kecil penyimpangan dalam koefisien regresi tersebut maka semakin berarti kontribusi variabel tersebut terhadap variabel tergantungnya. Uji $t$ digunakan untuk menguji signifikan pengaruh variabel independen terhadap 
variabel dependen. Pengujian ini menggunakan taraf signifikansi sebesar 0,05. Apabila nilai profitabilitas kurang dari 0,05 atau jika $t_{\text {hitung }} \geq t_{\text {tabel }}$, berarti ada pengaruh antara variabel independen secara signifikan terhadap variabel dependen begitu sebaliknya (Ghozali, 2013:65).

Berdasarkan tabel 2 diketahui bahwa variabel Good Corporate Governance (GCG) diperoleh nilai $t_{\text {hitung }}=3,946$ dan probabilitas sebesar 0,004. Jika dibandingkan dengan $t_{\text {tabel }} 2,074$ maka $t_{\text {hitung }} 3,946 \geq t_{\text {tabel }} 2,074$ dan $\rho 0,004 \leq 0,05$. Hal ini menunjukan bahwa Ha diterima, artinya Good Corporate Governance (GCG) berpengaruh secara signifikan terhadap ROA Bank Syariah. Kemudian Hasil Uji Regresi Sederhananya sebagai berikut:

Tabel 2 Hasil Uji Regresi Linier Sederhana

\begin{tabular}{|c|c|c|c|c|c|c|}
\hline \multicolumn{7}{|c|}{ ANOVA $^{\mathrm{a}}$} \\
\hline Model & & $\begin{array}{l}\text { Sum of } \\
\text { Squares }\end{array}$ & Df & $\begin{array}{l}\text { Mean } \\
\text { Square }\end{array}$ & $\mathrm{F}$ & Sig. \\
\hline \multirow[t]{2}{*}{1} & $\begin{array}{l}\text { Regressio } \\
\mathrm{n}\end{array}$ & 37,032 & 1 & 37,032 & 10,515 &, $004^{b}$ \\
\hline & $\begin{array}{l}\text { Residual } \\
\text { Total }\end{array}$ & $\begin{array}{l}77,491 \\
114,522\end{array}$ & $\begin{array}{l}22 \\
23\end{array}$ & 3,522 & & \\
\hline
\end{tabular}

a. Dependent Variable: Y

b. Predictors: (Constant), $\mathrm{X}$

Berdasarkan tabel 2 diperoleh nilai $\mathrm{F}_{\text {hitung }}=10,515$ dan probabilitas sebesar 0,004. Jika dibandingkan dengan $\mathrm{F}_{\text {tabel }} 4,30$ maka $\mathrm{F}_{\text {hitung }} 10,515 \geq \mathrm{F}_{\text {tabel }} 4,30$ dan $\rho 0,004$ $\leq$ 0,05 dapat disimpulkan bahwa variabel independen/X Good Corporate Governance (GCG) mempengaruhi variabel dependen/Y kinerja keuangan secara signifikan atau hipotesis diterima.

Good Corporate Governance (GCG) berpengaruh positif dan signifikan terhadap ROA Bank Umum Syariah. Hal ini ditunjukkan sesuai hasil uji regresi sederhana dengan nilai $F_{\text {hitung }}$ sebesar 10,515. Jika dibandingkan dengan nilai $F_{\text {tabel }}$ 4,30 maka $\mathrm{F}_{\text {hitung }} 10,515 \geq \mathrm{F}_{\text {tabel }}$ 4,30. Hal ini dapat dinyatakan pula berdasarkan uji $\mathrm{t}$ variabel Good Corporate Governance (GCG) dengan nilai $t_{\text {hitung }}$ sebesar 3,946 dan probabilitas sebesar 0,004 . Jika dibandingkan dengan $t_{\text {tabel }} 2,074$ maka $t_{\text {hitung }} 3,946 \geq$ $\mathrm{t}_{\text {tabel }}$ 2,074 dan $\rho$ 0,004 $\leq 0,05$ maka Ho ditolak dan Ha diterima artinya terdapat pengaruh positif signifikan antara GCG terhadap ROA. Artinya jika Good Corporate Governance (GCG) pada Bank Umum Syariah dalam pengelolaannya berjalan baik dan mengalami peningkatan, maka semakin besar pula tingkat ROA yang diperoleh oleh Bank Umum Syariah. Dari tabel hasil analisis regresi, menunjukkan bahwa model persamaan regresi sederhana untuk memperkirakan GCG yang dipengaruhi oleh ROA. Hasil tersebut dapat dijelaskan bahwa nilai konstanta (a) sebesar -2,951, artinya apabila GCG bernilai 0, maka nilai ROA sebesar -2,951.

\section{Uji Determinasi $\left(\mathbf{R}^{2}\right)$}

Koefisien determinasi adalah salah satu nilai statistik yang dapat digunakan untuk mengetahui apakah ada pengaruh antara dua variabel. Nilai koefisien determinasi menunjukan presentaase variasi nilai variabel dependen yang dapat dijelaskan oleh persamaan regresi yang dihasilkan (Algifari, 2011:20). Nilai $\mathrm{R}^{2}$ yang kecil berarti kemampuan variabel independendalam menjelaskan variabel dependenkecil. Sedangkan jika nilai $\mathrm{R}^{2}$ besar atau mendekati satu maka hampir semua informasi yang dibutuhkan dapat memprediksi variabel dependen (Amalia dan Fidiana, 2016:9). 
Tabel 3 Hasil Uji Koefisien Determinasi $\left(\mathbf{R}^{2}\right)$

Model Summary

\begin{tabular}{llrrrr}
\cline { 5 - 6 } Model & $\mathrm{R}$ & R Square & & Adjusted R Square & Std. Error of the Estimate \\
\hline 1 &, $569^{\mathrm{a}}$ &, 323 &, 293 & 1,876778
\end{tabular}

a. Predictors: (Constant), $\mathrm{X}$

b. Dependent Variable: Y

Berdasarkan tabel 3 dapat diketahui $\mathrm{R}$ sebesar 0,569 yang menunjukkan korelasi antara variabel independen dengan variabel dependen. Hasil dari $R$ Square sebesar 0,323 atau 32,3\% yang artinya variabel dependen (ROA) dapat dijelaskan oleh variabel independen (GCG) sebesar 32,3\%. Sedangkan sisanya $(100 \%-32,3 \%=$ $67,7 \%)$ dijelaskan oleh variabel lain diluar model atau dapat dikatakan sempurna (100\%) apabila ada variabel independent lain yang dimasukkan ke dalam model. Dengan kata lain, Good Corporate Governance (GCG) memberi pengaruh sekitar 32,3\% terhadap ROA Bank Syariah di Indonesia.

Adjusted $R$ Square menunjukkan koefisien determinasi yang telah dijumlah dengan varian dan ukuran sampel sehingga dapat mengurangi unsur jika terjadi penambahan variabel ukuran sampel. Besar Adjusted $R$ Square 0,293 yang berarti variabel GCG (X) dijelaskan oleh variabel kinerja keuangan (Y) sebesar 29,3\%. Std. Error of the Estimate adalah penyimpangan antara persamaan regresi dengan dependen riilnya, yaitu sebesar 1,877 satuan variabel dependen (jika GCG dihitung dalam satuan, maka besarnya penyimpangan adalah 1,877 juta). Semakin kecil nilai standard, maka semakin baik persamaan regresi tersebut sebagai alat prediksi.

Hasil uji determinasi diketahui pengaruh dari kedua variabel independen GCG terhadap dependen kinerja keuangan (ROA) dinyatakan dalam nilai $\mathrm{R}^{2} \times 100 \%$ yaitu sebesar 0,323 atau 32,3\%. Artinya 32,3\% variabel dependen (ROA) bisa dijelaskan oleh variabel independen (GCG). Berarti variabel GCG berpengaruh kurang dominan (lemah) terhadap kinerja keuangan dikarenakan nilai $R$ Square dibawah 50\%. Sedangkan $67,7 \%$ sisanya dijelaskan oleh variabel yang lain diluar model penelitian ini atau dapat dikatakan sempurna (100\%) apabila ada variabel independent lain yang dimasukkan ke dalam model. Dengan kata lain, Good Corporate Governance (GCG) memberi pengaruh sekitar 32,3\% terhadap ROA Bank Syariah di Indonesia.

\section{Pembahasan}

Hasil self assessment terhadap seluruh faktor pelaksanaan GCG, predikat pelaksanaan tata kelola perusahaan, dan nilai komposit yang dilakukan oleh delapan bank umum syariah tersebut adalah baik. Bank yang mendapat nilai komposit "Sangat baik" mulai tahun 2016-2018 adalah BSM dan BCA Syariah. Yang mendapatkan nilai komposit "Baik" yakni BRI Syariah, BNI Syariah, Bank Mega Syariah, Bank Syariah Bukopin, dan BTPN Syariah. Sedangkan bank yang mendapatkan nilai komposit "Cukup baik" adalah Bank Muamalat Indonesia. Hal ini menunjukkan bahwa semakin baik GCG yang diterapkan maka akan semakin meningkat pula tingkat ROA perbankan tersebut. Good Corporate Governance diukur dengan menggunakan nilai komposit Self Assessment. Predikat baik yang diperoleh dari penilaian self assessment menunjukkan bahwa perbankan syariah amanah dalam menjalankan tugasnya. Dalam artian, banyak masyarakat yang percaya terhadap perbankan syariah sehingga dapat menarik para investor untuk investasi di bank tersebut. Sesuai dengan firman Allah surat An Nisa' ayat 58:

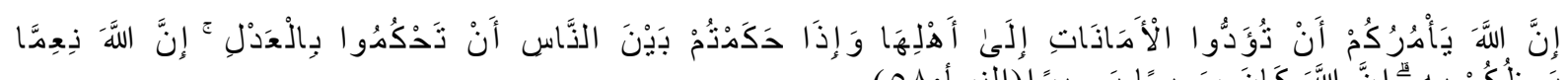

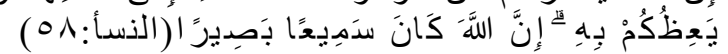

Artinya:"Sesungguhnya Allah menyuruh kamu menyampaikan amanat kepada yang berhak menerimanya, dan (menyuruh kamu) apabila menetapkan hukum

90 Asersi: Jurnal Akuntansi Terapan dan Bisnis

| Vol. 1, No. 1, 2021, \{83-94\}| ISSN 2807-243X (online version) 
di antara manusia supaya kamu menetapkan dengan adil. Sesungguhnya Allah memberi pengajaran yang sebaik-baiknya kepadamu. Sesungguhnya Allah adalah Maha Mendengar lagi Maha Melihat" (Al-Qur'an dan Terjemahnya Al-Quddus, 2014:86).

Ayat diatas dengan jelas telah menerangkan mengenai dianjurkannya bersikap adil baik dalam hal amanat maupun penetapan hukum. Dengan sikap adil maka tumbuhlah kepercayaan investor terhadap perbankan. Hal ini sesuai dengan pernyataan yang diungkapkan oleh Siswanti (2017) bahwa tujuan GCG dalam perbankan syariah ialah untuk menegakkan keadilan, kejujuran dan perlindungan terhadap kebutuhan manusia sesuai dengan maqashid syariah. Selain itu, tujuan GCG sendiri adalah untuk menciptakan nilai tambah melalui peningkatan kepercayaan para stakeholders (pihak yang berkepentingan).

Hasil perhitungan ROA dalam penelitian ini menunjukkan bahwa perkembangan ROA perbankan syariah di Indonesia tahun 2016-2018 cukup baik bahkan ditahun 2018 mengalami peningkatan. Di tahun 2016 dan 2017 ROA yang dimiliki oleh perbankan syariah mencapai 1,35\%. Sedangkan tahun 2018 nilai ROA bertambah 0,9\% yakni sebesar 1,44\%. Walaupun peningkatan ROA dari tahun ke tahun tidak terlalu besar, setidaknya tidak mengalami penurunan. Sesuai dengan penelitian terdahulu, salah satu untuk meningkatkan kinerja perusahaan ialah dengan meningkatkan nilai profitabilitas. Sedangkan dorongan utama nilai profitabilitas itu dengan meningkatkan laba. Laba yang diperoleh perbankan akan meningkat ketika pertumbuhan pembiayaan suatu bank itu berkualitas.

Rasio profitabilitas menurun salah satunya disebabkan karena menurunnya suku bagi hasil perbankan syariah. Turunnya suku bagi hasil pinjaman akan mengakibatkan margin bank menipis. Hal tersebut dapat menyebabkan pendapatan bank menurun, jika manajemen bank tidak memiliki kreativitas untuk menggali sumber pendapatan yang lain. Kedua, masih adanya potensi kenaikan rasio kredit bermasalah (Non Performing Loan/NPL). Keadaan yang seperti ini harus lebih diantisipasi seperti meningkatkan biaya pencadangan karena kondisi NPL yang rendah tidak menutup kemungkinan masih bisa naik. Kenaikan NPL biasanya terjadi karena pemulihan ekonomi yang belum merata (Antara, 2018).

Hal ini berbanding lurus dengan hipotesis bahwa kinerja keuangan suatu perbankan ditentukan oleh sejauh mana keseriusan perbankan dalam menerapkan GoodCorporate Governance (GCG). Secara hasil, penelitian ini sesuai yang menyatakan penerapan Good Corporate Governance (GCG) bermanfaat untuk meningkatkan kinerja keuangan perbankan.Semakin baik Corporate Governance yang dimiliki suatu perbankan maka diharapkan semakin baik pula kinerja dari suatu perbankan tersebut. Hasil penelitian ini mendukung penelitian yang dilakukan oleh Arry Eksandy (2018) dan Karina Hapsari (2018) yang menyimpulkan bahwa penerapan Good Corporate Governance (GCG) dalam perbankan berpengaruh positif terhadap kinerja keuangan perbankan yang diproksikan dengan ROA.

\section{SIMPULAN}

Berdasarkan hasil penelitian dapat ditarik kesimpulan bahwa Good Corporate Governance (GCG) berpengaruh signifikan terhadap kinerja keuangan bank syariah di Indonesia. Penelitian ini sesuai dengan teori yang menyatakan penerapan Good Corporate Governance (GCG) bermanfaat untuk meningkatkan kinerja keuangan perbankan. Semakin baik Corporate Governance yang dimiliki suatu perbankan maka semakin baik pula kinerja perbankan tersebut. Karena, dalam praktik GCG sangat membutuhkan organ bank yang berkepribadian sesuai dengan prinsip syariah seperti tidak luput dari sikap jujur, adil, amanah dan lain sebagainya. Hal 
tersebut dapat meningkatkan tingkat kepercayaan masyarakat terhadap perbankan syariah sehingga berpengaruh terhadap kinerja keuangan bank.

Keterbatasan dalam penelitian ini diantaranya adalah hanya dilakukan pada 8 Bank Umum Syariah saja, yaitu BCA Syariah, Bank Muamalat Indonesia, Bank Syariah Mandiri, BRI Syariah, BNI Syariah, Bank Bukopin Syariah, Bank Mega Syariah, dan Bank Tabungan Pensiunan Nasional Syariah, Penelitian ini hanya menggunakan data sekunder yakni berupa laporan tahunan masing-masing bank yang dipublikasikan dalam bentuk Annual Report secara lengkap, Variabel independen dalam penelitian ini dengan menggunakan 11 indikator yakni Pelaksanaan tugas dan tanggung jawab Dewan Komisaris, Pelaksanaan tugas dan tanggung jawab Direksi, Kelengkapan dan pelaksanaan tugas Komite, Pelaksanaan tugas dan tanggung jawab Dewan Pengawas Syariah, Pelaksanaan prinsip syariah dalam kegiatan penghimpunan dana dan penyaluran dana serta pelayanan jasa, Penanganan benturan kepentingan, Penerapan fungsi kepatuhan bank, Penerapan fungsi Audit Intern, Penerapan fungsi Audit Ekstern, Batas maksimum penyaluran dana, Transparansi kondisi keuangan dan non keuangan,laporan pelaksanaan GCG dan laporan internal. Sedangkan variabel dependen dalam penelitian ini hanya menggunakan rasio profitabilitas yaitu ROA. Oleh karena itu, dalam hal ini peneliti menyarankan bagi peneliti selanjutnya agar menambah variabel lainnya yang kemungkinan dapat memberi potensi pengaruh terhadap kinerja keuangan Bank Syariah. Dalam segi obyek sebaiknya tidak hanya Bank Umum Syariah (BUS) tetapi menggunakan industri perbankan syariah lainnya seperti Unit Usaha Syariah (UUS) dan Bank Perkreditan Rakyat Syariah (BPRS) agar cakupan penelitian lebih luas. Kemudian bagi para pengelola bank syariah perlu membuat dokumentasi eksposur risiko yang terjadi seperti penyebab, bentuk, dampak yang ditimbulkan dan hikmah yang bisa diambil. Tujuannya adalah untuk meminimalisir risiko yang terjadi dan agar tidak terulang lagi dikemudian hari.

\section{DAFTAR RUJUKAN}

Abdullah, Mal An. 2010. Corporate Governance Perbankan Syariah Di Indonesia. Jogjakarta: Ar-Ruzz Media.

Ahmad, A., Muhammad, M., \& Narullia, D. (2021). CORPORATE RISK DISCLOSURE: THE EFFECT OF CORPORATE GOVERNANCE. JOURNAL OF APPLIED MANAGERIAL ACCOUNTING, 5(1), 101-113.

Al Qur'an dan Terjemahnya Al Quddus. 2014. Kudus. Departemen Agama RI Arikunto, Suharsimi. 2010. Prosedur Penelitian Suatu Pendekatan Praktik. Jakarta: Rineka Cipta.

Budiman, Arif. 2017. Pengaruh Good Corporate Governance Terhadap Kinerja

Keuangan Bank Syariah. Artikel Publikasi Ilmiah.

Ekaningsih, Lely Ana Ferawati, 2011. Analisis Perbandingan Penilaian Kinerja Perusahaan di Bursa Efek Indonesia. Jurnal Akuntansi Universitas Jember 9 (2). https://core.ac.uk/download/pdf/304221584.pdf

Ekaningsih, Lely Ana Ferawati, dan Roziq, Ahmad. 2012. Rasio-Rasio Yang Membedakan (Discriminator) kinerja keuangan antara kelompok perbankan syariah dan kelompok perbankan konvensional di Indonesia. JEAM Vol. X1 No $1 / 2012$.

jurnal.unej.ac.id/index.php/JEAM/article/download/1195/958

92 Asersi: Jurnal Akuntansi Terapan dan Bisnis

| Vol. 1, No. 1, 2021, \{83-94\}| ISSN 2807-243X (online version) 
Ekaningsih, Lely Ana Ferawati, dkk. 2016. Lembaga Keuangan Syariah Bank \& NonBank. Surabaya: Kopertais.

Eksandy, Arry. 2018. Pengaruh Good Corporate Governance Terhadap Kinerja Keuangan Pada Perbankan Syari'ah Indonesia. Jurnal Akuntansi, Vol. V, No. $1: 1-8$.

Erfina, Erzy. 2014. Pengaruh Good Corporate Governance Terhadap Kinerja Keuangan Perbankan Syariah Di Indonesia. Artikel Publikasi Ilmiah.

Fahmi, Irham. 2012. Manajemen Keuangan. Bandung: ALFABETA cv.

Ghozali, Imam. 2006. Aplikasi Analisis Multivariate dengan Program SPSS. Semarang: Badan Penerbit Universitas Diponegoro.

Hanafi, Mamduh M. \& Halim, Abdul. 2014. Analisis Laporan Keuangan. Yogyakarta: UPP STIM YKPN.

Hapsari, Karina. 2018. Pengaruh Good Corporate Governance Terhadap Kinerja Keuangan di Bank Umum Syariah Pada Tahun 2013-2015. Skripsi

Huda, Nurul. \& Nasution, Mustafa Edwin. 2009. Current Issues Lembaga Keuangan Syariah. Jakarta: Kencana.

Husaini, Usman dan Purnomo, Akbar. 2008. Pengantar Statistika. Jakarta: PT Bumi Aksara.

Kasmir. 2015. Analisis Laporan Keuangan. Jakarta. PT RAJAGRAFINDO PERSADA.

Lewis, Mervyn K. dan Algaoud, Latifa M. 2003. Perbankan Syariah Prinsip, Praktik, dan Prospek. Jakarta: PT Serambi Ilmu Semesta.

Marsono. 2016. Metode penelitian kuantitatif. Bogor: IN MEDIA.

Muhammad. 2016. Manajemen Keuangan Syari'ah. Yogyakarta: UPP STIM YKPN.

Nugroho, Any. 2015. Hukum Perbankan Syariah. Yogyakarta: ASWAJA PRESSINDO.

Prabowo, Muhammad Shidqon. 2018. Dasar-Dasar Good Corporate Governance. Yogyakarta: UUI Press Yogyakarta.

PT Bank Central Asia Syariah. 2016-2018. Annual Report PT Bank Central Asia Syariah.http://www.bcasyariah.co.id/media/2017/04/Annual\%20Report\%2020 16.pdf (Diakses pada 23 Mei 2019).

PT Bank Mega Syariah. 2016-2018. Annual Report PT Bank Mega Syariahfile:///C:/Users/uSeR /Downloads/Annual_Report_2018.pdf (Diakses pada 24 Mei 2019).

PT Bank Muamalat Indonesia. 2016-2018. Annual Report PT Bank Muamalat Indonesia.https://www.bankmuamalat.co.id/uploads/hubungan_investor/2 annual-report-2018.pdf (Diakses pada 2 April 2019).

PT Bank Negara Indonesia Syariah. 2016-2018. Annual Report PT Bank Negara IndonesiaSyariah.https://www.bnisyariah.co.id/Portals/1/BNISyariah/Perusaha an/Hubungan\%20Investor/Laporan\%20Tahunan/PDF/revisi/bnis-laporantahunan-2017 dikompresi.pdf (Diakses pada23 Mei 2019).

PT Bank Syariah Bukopin. 2016-2018. Annual Report PT Bank Syariah Bukopin. https://www.syariahbukopin.co.id/public/uploads/report/AR_BSB_2016_OK_c ompressed.pdf (Diakses pada 24 Mei 2019).

PT Bank Rakyat Indonesia Syariah. 2016-2018. Annual Report PT Bank Rakyat IndonesiaSyariah.https://www.brisyariah.co.id/images/upload/reports/c8b256 1a533fa87d44300219e0308eb2_Laporan_Tahunan. pdf (Diakses pada 23 Mei 2019). 
PT Bank Syariah Mandiri. 2016-2018. Annual Report PT Bank Syariah Mandiri. https://www.mandirisyariah.co.id/assets/pdf/annualreport/AR_2018_Mandiri _Syariah_18052019.pdf (Diakses pada 23 Mei 2019).

PT Bank Tabungan Pensiunan Nasional Syariah. 2016-2018. Annual Report PT Bank Tabungan Pensiunan Nasional Syariah. https://www.btpn.com/pdf/investor/annual-report/en/ar-btpn-2018 eng_-.pdf (Diakses pada 24 Mei 2019).

Riduwan \& Sunarto. 2017. Pengantar Statistika Untuk Penelitian Pendidikan, Sosial, Ekonomi, Komunikasi dan Bisnis. Bandung: ALFABETA.

Subagiyo, Rokhmat. 2017. Metode Penelitian Ekonomi Islam. Jakarta Timur: Alim's Publishing.

Sugiyono. 2016. Metode penelitian kuantitatif, kualitatif, R\&D. Bandung: ALFABETA $\mathrm{CV}$.

Sugiyono. 2006. Statistika Untuk Penelitian. Bandung: CV ALFABETA.

Susanto, H. \& Umam, K. 2013. Manajemen Pemasaran Bank Syariah. Bandung: Pustaka Setia.

Sutedi, Adrian. 2012. Good Corporate Governance. Jakarta: Sinar Grafika.

Suwiknyo, Dwi. 2010. Ayat-Ayat Ekonomi Islam. Yogyakarta: PUSTAKA PELAJAR.

Warde, Ibrahim. 2009. Islamic Finance Keuangan Islam Dalam Perekonomian Global. Yogyakarta: Pustaka Pelajar.

Wiroso. 2011. Akuntansi Transaksi Syariah. Jakarta: IAI

https://www.bankmuamalat.co.id/profil-bank-muamalat (Diakses pada 14 April 2019).

https://www.cermati.com/artikel/sejarah-dan-perkembangan-bank-syariah-diindonesia (Diakses pada 17 April 2019).

https://www.merdeka.com/uang/kondisi-ekonomi-saat-ini-berbeda-dengan-krisis1998-dan-2008.html (Diakses pada 14 April 2019).

https://www.seputarpengetahuan.co.id/2017/08/pengertian-kinerja-keuanganmenurut-para-ahli-tujuan-pengukuran-dan-penilaian-analisis.html

(Diakses pada 14 April 2019). 